\title{
Spaces of early childhood: Spatial approaches in research on early childhood education and care
}

Sabine Bollig, Zsuzsa Millei

Keywords: spaces of childhood, spaces for children, spatial theorizing, space, early childhood education and care, childhood studies.

When Friedrich Froebel established his first 'Kindergarten' in late 1830s, he chose purposefully the name of this institute, dedicated to educating young children in radically new ways by means of play and guided activities. For him, the term 'Kindergarten' - the garden of children - signified two spaces "a garden for children, a location where they can observe and interact with nature, and also a garden of children, where they themselves can grow and develop in freedom from arbitrary imperatives" ${ }^{1}$. As a paradise 'given back to the children', the Kindergarten was construed as a confined, protected non-societal place where the innocent children could grow to full potential. Hence, as such a natural place aside from adult's society - that similarly to Rousseau he has seen as corrupted -, the kindergarten was not just a place for educating young children. Rather, it was a whole new kind of spatial arrangement to let the children come to their dignity in substance with god and nature and, therefore, become through their play the founders of a more human future society.

\footnotetext{
http://www.froebelweb.org/
} 
These foundational ideas of early childhood education demonstrates how ideas of children's nature and their proper education are very much bound to (utopian) spatial imaginaries and arrangements (e.g., Gulløv, 2003). With its idea of a non-societal place for the youngest, it furthermore shows how modern childhood cannot be understood without considering the processes of spatial separation - the "demarcation of specific places within which children are gathered, primarily for the purposes of play, learning and 'caring" (Kernan \& Devine, 2010, p. 371). Thus, the production of 'childhood spaces' was crucial for the modern process of institutionalizing childhood, based on the significant processes of children's 'relegation' away from the streets to the home, and from the labour market into schools, youth centers and the early childhood education and care (ECEC) services. As parts of the shifting 'civilizing project' (Gilliam \& Gulløv, 2017) towards the youngest, those childhood spaces have ever been filled with images, expectations, rationales and norms about children's needs and nature. And this is also why, how Zeiher \& Zeiher (1994) notes, the places that children find for themselves show specifically which position a society assigns to them (see also Aitken, 1994; Philo, 2000).

Given this underlying relation between space and childhood, the massive expansion of ECEC services taking place in recent decades (and decades earlier in former socialist regions) is thus not just accompanied by academic concerns about raising the quality of and professionalization within the field of ECEC. There is also a growing field of research that explores how this expansion of early childhood spaces reorganises the formerly 'private life' of the youngest and by that, reconstruct and change our concepts of children's place within society, the spatialities of proper childhood and the normal and good family as well (e.g., Dencik, 1989; Gulløv, 2003; Kjørholt $\&$ Qvortrup, 2012; Zeiher, 2009). Studies focusing on processes, such as the 'domestication' and 'insularisation' of childhood (Holloway \& Valentine, 2000; Zeiher, 2001) during the late modern period, give special attention to strategies of norming and civilising that operate within spatial regulations. In the case of the 'domestication' of children, the more and more disconnected, contained and supervised places assigned for children for instance extended children's regulation to their most specific activities, such as finemotor skills in crafts and imaginary play, as developmentally beneficial domestic occupations for children. Likewise, more recent spatial regimes in early childhood, such as the flexibilization of ECEC services leading to more free use of time and space in day care institutions, positions children to become 'self-managing choice-makers' (Kjørholt \& Seland, 2012; Millei, 2012). The constructions of spaces for childhood, therefore, do not only allocate 
certain spaces to children. As interrelations of emplacement, positioning, and subjectivation they also form the basis for the day-to-day experiences of being a child. In other words: they locate children's shifting identities (Bollig, 2018).

It would be, however, misleading to understand institutional childhood spaces only as spaces of adult regulation of children in society. Spatial perspectives in childhood studies also raise important questions about children's own geographies, or children's spaces in contrast to those assigned to children by adults, such as children's services (Moss \& Petrie, 2002). Based on the agency-paradigm of the so called childhood studies which consider children as active agents who lead their lives (e.g., Bollig $\&$ Kelle, 2016; Qvortrup, Corsaro \& Honig, 2009), there is also a rapidly expanding field of children's geographies which focus on how children create their own places and spaces in their encounters with private and public spheres, and how their learning and socialization processes are embedded in those (e.g., Blazek \& Kraftl, 2015; Christensen \& O'Brien, 2003; Holloway \& Jöns, 2012; Holt, 2011; Mills \& Kraftl, 2014). Related studies in the field of ECEC richly illustrate, for instance, how children use their spatial surroundings to make the transition to daycare (Brooker, 2014; Rutanen, 2017) and develop discrete spaces of well-being, autonomy and belonging within ECEC services and related peer cultural activities (Gallacher, 2005; Harrison \& Sumsion, 2014; Løkken \& Moser, 2012; Sumsion, Stratigos \& Bradley, 2014). Both perspectives, childhood spaces and children's spaces, inform also a growing research field concerned with the changing topographies and landscapes of care and education (e.g., Holloway \& Pimlott-Wilson, 2014; Vanderbeck \& Dunkley, 2004).

\section{Spatial Theorizations in ECEC}

The expansion of ECEC services offered good examples for geographers to explore modernization processes and the separation, operation and negotiations of childhood spaces in society both from a structural, and sociological interest in children as social actors (Holloway \& Valentine, 2000). The academic field of ECEC, however, had only sporadic discussions about the utility of spatial theorizations for the understanding of childhood spaces and children's spaces. In this introduction, therefore, we consider some productive ways to explore the continuously changing spatial regimes and the places and spaces creatively produced by children within these institutions. These studies are urgently needed, since in our societies currently undergoing rapid changes, places and spaces assigned for children and their rela- 
tions to other spaces in society are also in flux. ECEC has less to do today with Froebel's radical conception of place aside from society, rather it is an important place within and serving significant roles in society.

Today, ECEC is considered as an economic enterprise that produces human capital for society (Kjorholt, 2013; Lightfoot \& Peach, 2015; Millei \& Joronen, 2016), and governments seek to solve societal problems through ECEC, such as the care crisis of modern society manifesting in balancing flexible employment requirements and child care responsibilities in families (Léon, 2014; Michel \& Mahon, 2002). ECEC is also taken as a useful platform to solve issues of societal cohesion and nation building within countries reshaped by migration (Millei \& Imre, 2015; Seele, 2016) or the increasing poverty, deprivation and disenfranchisement of young people (Moss, 2015; Urban, 2014). Within the EU-countries, for example, ECEC services are more and more conceptualized as community centres placed in the very heart of regional educational landscapes and serve as central bridges between family and society, at the same time extending governments' reach into the private lives of their citizens (e.g., Richter $\&$ Andresen, 2012). Understanding ECEC as very-societal places, therefore, does not only change our conceptions of the spaces assigned for and reconstructed by children, but also leads to questions about the changing spatialities between family, governments, society and ECEC.

Early childhood education and care has also become a societal place as a result of intertwined developments in multiple spheres of influence, such as children's rights movements recognising children as citizens in societies; the development of childhood studies considering children as agentic actors contributing to societies at present not only in the future; and ECEC research that facilitates the operationalisation of children's rights and participation in early childhood curricula and pedagogies and in broader society, for example, in areas of citizenship education, sustainability, or social and global justice. In children's services, children are increasingly granted agencies to act as citizens and participate in the governance of their lives (e.g., Millei \& Imre, 2009), even though their political participation is limited (e.g., Millei \& Kallio, 2018). They are also considered as 'global' and 'cosmopolitan' citizens who can contribute to solving large scale challenges of creating harmonious societies and tackling human caused global environmental crisis (Duhn, 2014; Hägglund \& Pramling Samuelsson, 2009). These views on children and childhood first, acknowledge and encourage children to create their own spaces and lead their lives within those according to their decisions, and second, locate children firmly, but also in very ambiguous, am- 
bivalent and ethically challenging relations with their families and societies as participants on their own rights.

All this shows the potential for investing more into research on the relations of childhood and space in ECEC. Hence, they also call for new spatial approaches which are connected to at least three recent movements within scholarly work on childhood and space (Bollig, 2018).

First, the notion of homogenous childhood spaces gets more and more contested in regard to questions of how they include children differently in institutional processes taking place in increasingly porous spaces. Within the context of new references to societal and welfare agendas and cultural analysis, the focus is no longer on such 'big patterns' like 'institutionalized childhood' alone that have been earlier investigated with structural approaches. Rather, new foci include manifold, ambivalent and contradictory forms of institutionalized childhood and through that the production of diverse childhoods as well. Thus, emphasis is placed on the fragility, uncertainty and ambiguity (Hengst, 2018) of concurrent differential patterns of childhood(s) within contemporary society (Zinnecker, 2004) and their related "multiple becomings" (Lee, 2001), the unequal forms of children's lives (Lareau, 2011), and the differentiating regulations, discourses and practices that enforce various standards for different childhood groups (Betz, Bischoff \& Kayser, 2017; Holloway \& Pimlott-Wilson, 2014).

With regard to the field of ECEC, it is highlighted that this is a complex and fragmented policy area in which at all scales (global, national, local) numerous ambiguities, tensions and contradictions co-exist (Press \& Woodrow, 2005). It is especially so if we take into account recent welfare transformations particularly apparent in the field of ECEC as it spans the state, the market, and the family and several policy areas (Penn, 2011). In consequence, we have to speak geographically about very much uneven ECEC landscapes (Bollig, 2015; England, 1996; Vandenbroeck et al, 2008). Moreover, and given to the multitude of functions ECEC services designed to meet and the diverse desires and needs of families, the politics of placing children in early childhood services are not just "filled with paradoxes, ambiguities and negotiations" (Gulløv, 2003, p. 36), but also with inconsistently layered and chronologically shifting conceptions of 'good ECEC childhood' and children's respective sense of place.

Second, globalization and changed patterns of mobility have allowed for the emergence of new types of spatial references. Altered conditions of pro- 
duction and consumption, and migration-related movements lead to a far more complex spatialization of children and childhoods (e.g., Faulstich Orellana et al., 2001), both in everyday practical terms and in conceptual terms. The relations of space and childhood are therefore no longer be understood merely as spatial productions within nation-state 'containers', instead, they are analyzed in terms of their global-local, multiple-scaled, multilocal and transnational spatial relations (e.g., Mahon, 2006; Millei \& Jones, 2014; Wells, 2015).

Third, these new spatial relations are attended by those perspectives that have been modified in the course of the so-called 'spatial turns'. New spatial theory approaches are united first and foremost by the notion of ever open, complex and multiple productions of space understood as dynamic and relational arrangements of things and bodies through which social relationships are materialized, represented and reproduced (see for an overview Robertson, 2009). Here, from predominantly practice, post-structural and actor network theoretical perspectives, unified container-like and 'objective' spatial relations are negated, leading to new theorizations that better account for the diversity of childhood spaces, and which can help explore children's involvement in multiple productions of place and space. In this non-absolutist sense, space is seen as a relational category (e.g., Löw, 2008) where relations are embedded in the ongoing flow of carried-out practices and networked relations, space is inseparably interwoven with time, always in the process of being made and open-ended. Or in other words, space and time are taken as processual. Such a relational understanding of spatiality implies a simultaneous multiplicity of spaces which mutually limit each other, are interwoven, or else organize themselves paradoxically and antagonistically vis-à-vis each other. This also means that "social relations of space are experienced differently, and variously interpreted, by those holding different positions as part of it” (Massey, 1994, p. 3).

Given these developments, and more that we have no space to outline here $^{2}$, that inform and challenge our notion of early childhood spaces, there is a small but growing body of ECEC-related research which already demonstrates the wide ranging and productive insights new perspectives on space can offer: such as political strategies that produce certain and constructed scales of ECEC-governance (e.g., Mahon, 2006), related 'governable spaces of ECEC' (e.g., Gallagher, 2012), the production of a 'global educational

2 See for example the multi-volume reference on Geographies of Children and Young People edited by Tracey Skelton https://www.springer.com/series/13414 
space' (e.g., Millei \& Jones, 2014); educative spaces within ECEC services (e.g., Kjorholt \& Seland, 2013) and children's spatial strategies to take control and act autonomously within them (e.g., Gallacher, 2005). Although these studies rely on the same basic assumptions about space, they use quite diverse theoretical approaches, such as post-structural theories on space informed by Deleuze \& Guattari (e.g., Sumsion, Stratigos \& Bradley, 2014) as well as practice-analytical ones referring to Lefebvre (e.g., Rutanen, 2012), de Certeau (e.g., Schnoor, 2015) or Massey (e.g., Bollig, 2015), or perspectives based on post-colonial (e.g., Nxumalo \& Cedillo, 2017) and citizenship theories (e.g., Gustafson \& van der Burgt, 2015).

\section{The Contributions to this Special Issue}

By presenting a concerted engagement with these developments, this special issue wishes to offer a more comprehensive discussion about some spatial perspectives that are productive in exploring ECEC and children's negotiations of ECEC spaces within and outside the narrowly defined institutional place. The contributors to this special issue offer their perspectives and their uses of different spatial theorizing by cutting through spaces of ECEC institutions in their empirical examinations in ways specific to their orientations to space and place.

Gallagher explores how technological changes in the management of ECEC produce new spaces for the government of educators, parents and children's lives. She describes how the development and introduction of a new software for creating eportfolios aim to allow closer participation of parents in children's everyday activities in day care, aid educators' work to create documentation of children's learning, and help balancing working parents' responsibilities to be present also in their children's lives. However, she argues that through new virtual spaces created by this technology, the closer observation and regulation of educators as well as parents take place. Besides this new regime of governance, children are also subjected to new forms of visibilities that further open and enable the more intensive scrutinization of children's lives in these settings. Drawing on Actor Network Theory, she offers a rich conceptualisation of how technology can be researched as a form of materiality in ECEC, despite of its virtual nature, creating new spaces and bringing about new power relations contributing to the heterogeneity of ECEC spaces. In her conclusion, Gallagher poses a question for further exploration by asking what exactly is being documented through the eportfolio' given the new virtual spaces and visibilities it produces. 
Vuorisalo, Raittila and Rutanen's paper shows how autonomy, an important ideal of Finnish early childhood education, is being produced through the creation of multiple spaces by parents, educators and children related to their own positions in the institution. Through their relational analysis of data produced in a team ethnography, they highlight how autonomy unfolds within these spaces. Educators produce spaces of freedom for children within the constraints of institutional boundaries trusting that children act independently and suit themselves within educators' pedagogical aims. Children lead their lives within these spaces in and outside of educators' view and skilfully negotiate their own time and choices within those and the spaces educators assign to them. Most interestingly, educators expect children to fit in the rhythm of pedagogical work in a rapid manner upon starting preschool, so children can start to act independently and responsibly to fulfil pedagogical ideals. Parents construct the autonomous space of ECEC as their children's space separated from their life for a period of time during the day that they do not always know about. Their account contributes to understanding the preschool as an ideologically governed space that connects the preschool with larger projects aiming to shape children's subjectivities as citizens.

Green continues with the concept of autonomy but explores it in its particular form as 'spatial autonomy'. She sets out to further conceptualise this concept through empirical data produced in two research projects: one is in Alaska's outdoor places and the other in US children's family homes. She describes the various ways children enact their spatial autonomy by crafting their play places both inside and outside. Green shows how children creatively negotiate their play spaces, for example to intentionally avoid adults' gaze, to create private spaces, which in our view, might also fall outside of society and its rules, perhaps recreating the spaces Froebel imagined for children. She summarizes her findings and defines spatial autonomy as an expression of children's independence, influenced by and created in negotiations with adults and in relation with the human and non-human environment. She concludes her paper by pointing to the importance of spatial autonomy in children's emerging sense of self and confidence in their environments.

Children's encounters with nature and public spaces are also one of the perspectives Ekman Ladru and Gustafson take in raising attention to children's mobility through their study on a mobile preschool in Sweden. A mobile preschool continuously carries children to public places in a bus. Their article discusses how in public spaces children collectively create their own 
spaces for routines, collective movements and secret locations within teachers' concerns for their safety. The mobile preschool is thus seen as creating new relations between children's institutional life, their material surroundings and society. In referencing Masseys spatial thinking and along their close observation of the very prominent feature of 'walking-in-line', they show how those routines are entangled with the material and interactional spaces children reproduce and create within those routines. While being in a preschool site provides physical boundaries for rules and routines to be in effect in a more constant way, in a mobile preschool the boundaries are shifting and changing, continuously accommodating to the actual environment. By combining such a view on mobility and space with considerations about peer-culture, the authors argue that those walks create important social and learning spaces, because they allow children to move with and through multiple socio-material trajectories.

Instead of their spaces being expanded to include a variety of public spaces as institutional sites, 'babies' in Sumsion, Harrison and Stapleton's study are limited to a relatively small and enclosed environment. This place, initially perceived as very confined and confining, expands as we follow the authors' analysis in which they highlight the relational interactions children, their carers and the non-human things around them have as they together create for 'babies' a space of belonging. Using Massey's concepts blended with Deleuzian spatial theorizing the authors interpret how 'babies' might experience belonging through their encounters with the texture of the baby's room. Along a story (and possible other stories) of a baby's 'navigating moments' with a pink carnation they show how baby Nadia expands the spatial possibilities of belonging in their tiny room by intensifying space. Yet again, this paper adds to the multiple ways in which ECEC spaces can be theorized and the analytical insights spatial perspectives can produce. They also help drawing out less explored qualities of spaces that very young children create. Furthermore, their approach also raise important questions about the ethics of representation in research with very young children.

Aligning with its aim to discuss the quality of ECEC spaces, but perhaps in contrast to the very locale places of early care and education services, Millei reconceptualizes the preschool place as connected and layered with distant spatialities. She explores how children's images, ideas and imaginations of distant places embed in preschool activities as children emplace themselves in expanded spaces of the preschool in sensory and embodied ways. Operationalizing Massey's concept of 'global sense of place' to analyse ethnographic data produced in an Australian preschool, she portrays how 
places, bodies and objects entangle and participate in everyday activities, and how children create images of and inhabit the world in their sensory emplacements. Millei calls for more critical engagements with children's 'doings' that reproduce global power relations in potentially fixed and stereotypical representations of the world and that contribute to their relations with distant others and their identity formation as global and cosmopolitan citizens. With her study, she places an emphasis on the need to move away from interpretations that singularly focus on children's verbal sense making and include the rich ways for research offered if attention is paid to phenomenologies of children's emplacement in relational spaces that spread to the globe.

The next contribution also extends the gaze from one setting to multiple places of care and education. Bollig emphasizes the diverse spatialities that interplay in the 'daily accomplishment of ECEC' as children participate in multiple services during their days. With 'daily accomplishment', she refers to the ways in which institutional processes together with children's and parents' participation produce ECEC as it is provisioned. The complex Luxembourgian ECEC system provides a perfect focus to explore how ECEC systems unfold through children's everyday activities as shifting fields reproduced and transformed in children's own particular education and care arrangements. By using Schatzki's practice theory and Massey's concept of 'throwntogetherness of place', Bollig zooms into the linguistic landscapes of Luxembourgian ECEC and demonstrates how the spatiality of children's ECEC arrangements are produced through multiple spatial relations which intersect and align in places of ECEC. Through her analysis we can, thus, see how the complex and layered spaces of ECEC produced, are connected to wider spaces in society that are shaped by migration and the diversity of the Luxembourgian context, policy frames and organizational routines and with which children skilfully navigate, within and against the boundaries this ECEC system constructs. Bollig's study richly demonstrates the impossibility to produce insightful research if one explores ECEC today as a bounded and only institutionally framed place, and without considering also children's participation in the production of place.

Together these studies explore the utility of spatial theorizing for understanding complex, highly contextual and shifting positionings and realities of ECEC today and children's lives led within and across those institutions. De-centering many existing studies' engagement of ECEC places as bounded, they identify the multiplicity of spaces that coexist within an institution and that are in connections with multiple other spaces outside of it (that 
perhaps were considered unconsciously by many as part of society separated from these spaces). Focusing on the materialities, movements, constructions, embodiments, place-making, power relations and sensory experiences through which children create and experience the production of these spaces and their negotiations, contributors offer novel ways for experimenting with these ideas in further research on early childhood education and care.

In relation to the three recent movements discussed above, we can offer some preliminary, very short and inconclusive ideas here. First, spatial theorizing offers some needed conceptual tools to examine the many kind, manifold, connected, ambiguous and contradictory forms of the institutionalization of childhood and the creation of diverse childhoods during late modernity characterised by rapid change and technological advances, the more intense intertwining of societal and private spaces and their governance, and the diversification and expanding connectedness of spaces and multiple ECEC services in which and in between which children live and lead their lives. Second, contributors offered examples of how spatial conceptual tools enable to theorize children's ECEC spaces as intimately connected to and embedded within global processes, such as consumption, neo-colonialism, technological change, growing inequalities, diverse forms of governance of everyday life and mobility. Studies explicitly undertaking this task in the field of ECEC research are still rare. Third, spatial perspectives developed in these articles allowed to approximate children's different and diversifying positionings and experiences within global and local processes, public and private spaces, inside and outside environments. Authors paid particular attention to how different and unequal realities, belongings and opportunities for children within early care and education services and outside of but in relation to those were formed and re/produced.

Contributors also provoked further questions and opened avenues for follow-up research, for instance, about the changing or liminal spaces which are produced when technologies, institutional spaces and routines, and related to those children's affects, desires and so on, fold onto public places and vice versa. Or they put forward new foci for explorations, such as about the ways in which children intensify and expand spaces they inhabit, or the various and often (unrecognised) mundane and sensuous ways they encounter those and create encounters with the world. These also raise potentials to think about new forms of children's agencies which are produced by and negotiated within the complex spatialities those unfold within. With this special issue, our aim was to bring together researchers who work with spatial theories in ECEC and to continue and open up further discussions, 
and to inspire new studies that more intentionally use spatial theories in their explorations of early childhood spaces.

\section{Acknowledgements}

We thank all the reviewers who provided invaluable comments and feedback to authors in this special issue. We also thank the journal for providing language editing free of charge and open access to these important contributions to research in ECEC.

\section{References}

Aitken, S. C. (1994). Putting children in their place. Washington: Association of American Geographers.

Betz, T., Bischoff, S., \& Kayser, L. B. (2017). Unequal parents' perspectives on education. An empirical investigation of the symbolic power of political models of good parenthood in Germany. In T. Betz, M.-S. Honig, \& I. Ostner (Eds.), Parents in the spotlight. Parenting practices and support from a comparative perspective. [Special Issue]. Journal of Family Research, 11, 99-118.

Blazek, M., \& Kraftl, P. (2015). Children's emotions in policy and practice: Mapping and making spaces of childhood and youth. Basingstoke, UK: Palgrave.

Bollig, S. (2015). The multiple geographies of early childhood education and care: An ethnographic approach to the places and spaces of young children's care arrangements. In S. Bollig, M.-S. Honig, S. Neumann, \& C. Seele (Eds.), MultiPluriTrans in educational ethnography. Approaching the multimodality, plurality and translocality of educational realities (pp. 235-255). Bielefeld: transcript.

Bollig, S. (2018). Making places. Zu den Räumen ,betreuter Kindheiten‘. In T. Betz, S. Bollig, M. Joos, \& S. Neumann (Eds.), Institutionalisierungen von Kindheit. Childhood studies zwischen Soziologie und Erziehungswissenschaft (p. 111-128). Weinheim: Beltz Juventa.

Bollig, S., \& Kelle, H. (2016). Children as actors or as participants of practices? In F. Eßer, M. Baader, T. Betz, \& B. Hungerland (Eds.), Reconceptualising agency and childhood: New perspectives in childhood studies (pp. 34-47). London: Routledge.

Brooker, L. (2014). Making this my space: Infants' and toddlers' use of resources to make a day care setting their own. In L. Harrison, \& J. Sumsion (Eds.), Lived spaces of infant-toddler education and care. exploring diverse perspectives on theory, research and practice (pp. 29-42). New York: Springer.

Christensen, P., \& O'Brien, M. (Eds.). (2003). Children in the city: Home, neighbourhood and community. London: Routledge Falmer.

Dencik, L. (1989). Growing up in the post modern age: On the child's situation in the modern family, and on the position of the family in the modern welfare state. Acta Sociologica, 32(2), 155-180.

Duhn, I. (2014). Being and becoming cosmopolitan in early childhood curriculum: 'Roots', 'wings' and cosmopolitan citizenship. Global Studies of Childhood, 4(3), 224-234. 
England, K. (1996). Who will mind the baby? Geographies of childcare and working mothers. London: Routledge.

Faulstich Orellana, M., Thorne, B., Lam, W.S.E, \& Chee, A. (2001). Transnational childhoods: The participation of children in processes of family migration. Social Problems, 48(4), 572-591.

Gallacher, L.A. (2005). 'The terrible twos': Gaining control in the nursery? Children's Geographies, 3(2), 243-264.

Gallagher, A. (2012). Neoliberal governmentality and the re-spatialisation of childcare in Ireland. Geoforum, 43, 464-471.

Gilliam, L., \& Gulløv, E. (2017). Children of the welfare state: Civilising practices in schools, childcare and families. London: Pluto Press.

Gulløv, E. (2003). Creating a natural place for children: An ethnographic study of Danish kindergartens In K. Fog Olwig, \& E. Gulløv (Eds.), Children`s places - crosscultural perspectives (pp. 23-38). London: Routledge.

Gustafson, K., \& van der Burgt, D. (2015). 'Being on the move': Time-spatial organisation and mobility in a mobile preschool. Journal of Transport Geography, 46, 201-209.

Hägglund, S., \& Pramling Samuelsson, I. (2009). Early childhood education and learning for sustainable development and citizenship. International Journal of Early Childhood, 41(2), 49-63.

Harrison, L., \& Sumsion, J. (Eds.). (2014). Lived spaces of infant-toddler education and care. Dordrecht: Springer.

Hengst, H. (2018). Multiples Werden, lebenslanges Lernen. In T. Betz, S. Bollig, M. Joos, \& S. Neumann (Eds.), Institutionalisierungen von Kindheit. Childhood studies zwischen Soziologie und Erziehungswissenschaft (pp. 94-110). Weinheim: Beltz Juventa.

Holloway, S., \& Pimlott-Wilson, H. (2014). Enriching children, institutionalizing childhood? Geographies of play, extracurricular activities, and parenting in England. Annals of the Association of American Geographers, 104 (3), 613-627.

Holloway, S., \& Valentine, G. (2000). Children's geographies and the new social studies of childhood. In S. Holloway, \& G. Valentine (Eds.), Children's geographies: Playing, living, learning (pp. 1-28.) London: Routledge.

Holloway, S.L., \& Jöns, H. (2012). Geographies of education and learning. Transactions of the Institute of British Geographers, 37, 482-488.

Holt, L. (2011). Geographies of children, youth and families. An international perspective. London: Routledge.

Kernan, M., \& Devine, D. (2010). Being confined within? Constructions of the good childhood and outdoor play in early childhood education and care settings in Ireland. Children \& Society, 24(2), 371-385.

Kjørholt, A. T. (2013). Childhood as social investment, rights and the valuing of education. Children \& Society, 27(4), 245-257.

Kjørholt, A. T., \& Seland, M. (2012). Kindergarten as a bazaar. Freedom of choice and new forms of regulation. In A.T. Kjørholt, \& J. Qvortrup (Eds.), The Modern child and the flexible labour market (pp. 168-185). London: Palgrave Macmillan.

Kjørholt, A.T., \& Qvortrup, J. (Eds.). (2012). The modern child and the flexible labour market. London: Palgrave Macmillan. 
Lareau, A. (2011). Unequal childhoods. Class, race, and family life, with an update a decade later. Oakland: UC Press.

Lee, N. (2001). Growing up in an age of uncertainty. Buckingham: Open University Press.

León, M. (2014). Similar trends, different responses: The transformation of care in European societies. In M. León (Ed.), The transformation of care in European societies (pp. 324-337). London: Palgrave Macmillan.

Lightfoot, T., \& Peach, R. (Eds. ). (2015). Global perspectives on human capital in early childhood education, reconceptualizing theory, policy, and practice. New York: Palgrave.

Løkken, G., \& Moser, T. (2012). Space and materiality in early childhood pedagogy introductory notes. Education Inquiry, 3(3), 303-315.

Löw, M. (2008). The constitution of space. The structuration of spaces through the simultaneity of effect and perception. European Journal of Social Theory, 11(1), 25-49. Mahon, R. (2006). Of scalar hierarchies and welfare redesign: Child care in three Canadian cities. Transactions of the Institute of British Geographers, 31(4), 452-466. Massey, D. (1994). Space, place and gender. Minneapolis: University Press.

Massey, D. (2005). For space. London: Sage.

Michel. S., \& Mahon, R. (2002). Child care policy at the crossroads: Gender and welfare state restructuring. London: Routledge.

Millei, Z. (2012). Thinking differently about guidance: Power, children's autonomy and democratic environments. Journal of Early Childhood Research, 10(1), 88-99.

Millei, Z., \& Imre, R. (2009). The problems with using the concept of 'citizenship' in early years policy. Contemporary Issues in Early Childhood, 10(3), 279-290.

Millei, Z., \& Imre, R. (Eds.). (2015). Childhood and nation: Interdisciplinary engagements. New York: Palgrave MacMillan.

Millei, Z., \& Imre, R. (2016). 'Down the toilet': Spatial politics and young children's participation. In K. P. Kallio, \& S. Mills (Eds.), Politics, citizenship and rights (pp. 171-188). Singapore: Springer.

Millei, Z., \& Jones, A. (2014). The Australian early childhood curriculum and a cosmopolitan imaginary. International Journal of Early Childhood, 46 (1), 63-79.

Millei, Z., \& Joronen, M. (2016). The (bio)politicization of neuroscience in Australian early years policies: Fostering brain-resources as human capital. Journal of Education Policy, 31(4), 389-404.

Millei, Z., \& Kallio, K. P. (2018). Recognizing politics in the nursery: Early childhood education institutions as sites of mundane politics. Contemporary Issues in Early Childhood, 19(1), 31-47.

Mills, S., \& Kraftl, P. (2014). Informal education, childhood and youth: Geographies, histories, practices. Basingstoke: Palgrave.

Moss, P., \& Petrie, P. (2002). From children's services to children's spaces. London: Routledge Falmer.

Moss, P. (2015). There are alternatives! Contestation and hope in early childhood education. Global Studies of Childhood, 5(3), 226-238.

Nxumalo, F., \& Cedillo, C. (2017). Decolonizing place in early childhood studies: Thinking with Indigenous onto-epistemologies and Black feminist geographies. Global studies of childhood, 7(2), 99-112. 
Philo, C. (2000). 'The corner-stones of my world': Editorial introduction to special issue on spaces of childhood. Childhood, 7(3), 243-256.

Qvortrup, J., Corsaro, W. A., \& Honig, M.-S. (2009). The Palgrave handbook of childhood studies. Houndmills: Palgrave Macmillan.

Richter, M., \& Andresen, S. (Eds.). (2012). The politicization of parenthood. Shifting private and public responsibilities in education and child rearing. New York: Springer. Roberston, S.L. (2009). 'Spatialising' the sociology of education: Stand-points, entrypoints, vantage-points. In S. Ball, M. Apple, \& L. Gandin (Eds.), Handbook of Sociology of Education (pp. 15-26). London, New York: Routledge.

Rutanen, N. (2012). Socio-spatial practices in a Finnish daycare group for one- to three-year-olds. Early Years: An International Research Journal, 32(2), 201-214.

Rutanen, N. (2017). Spatial perspective on everyday transitions within a toddler group care setting. In L. Li, G. Quiñones, \& A. Ridgway (Eds.), Studying babies and toddlers (pp. 49-62). Singapore: Springer.

Schnoor, O. (2015). Bringing sound back into space. Multimodal ethnography of early education. In S. Bollig, M.-S. Honig, S. Neumann, \& C. Seele (Eds.), MultiPluriTrans in educational ethnography. Approaching the multimodality, plurality and translocality of educational realities (pp. 235-255). Bielefeld: transcript.

Sumsion, J., Stratigos, T., \& Bradley, B. (2014). Babies in space. In L. Harrison, $\&$ J. Sumsion (Eds.), Lived spaces of infant-toddler education and care (pp. 43-58). Dordrecht: Springer.

Urban, M. (2014). Not solving problems, managing messes: Competent systems in early childhood education and care. Management in Education, 28 (4), 125-129.

Vandenbroeck, M., De Visscher, S., Van Nuffel, K., \& Ferla, J. (2008). Mothers' search for infant child care: The dynamic relation between availability and desirability in a continental european welfare state. Early Childhood Research Quarterly, 23(2), 245-258.

Vanderbeck, R., \& Dunkley, C. M. (2004). Introduction: Geographies of exclusion, inclusion and belonging in young lives. Children's Geographies, 2(2), 177-183.

Wells, K. (2015). Childhood in global perspective (2 ${ }^{\text {nd }}$ Ed.) Cambridge: Polity Press.

Zeiher, H. (2001). Children's islands in space and time: The impact of spatial differentiation on children's ways of shaping social life. In M. de Bois-Reymond, H. Sünker, \& H.-H. Krüger (Eds.), Childhood in Europe. Approaches - trends -findings (pp.139-159). New York: Peter Lang.

Zeiher, H., \& Zeiher, H. (1994). Orte und Zeiten der Kinder. Soziales Leben im Alltag von Großstadtkindern. Weinheim: Juventa.

Zeiher, H. (2009). Institutionalization as a secular trend. In J. Qvortrup, W. A. Corsaro, \& M.-S. Honig (Eds.), The palgrave handbook of childhood studies (pp. 127-139). London: Palgrave Macmillan.

Zinnecker, J. (2004). Konkurrierende Modelle von Kindheit in der Moderne. In D. Geulen, \& H. Veith (Eds.), Sozialisationstheorie interdisziplinär (pp. 293-316). Stuttgart: Lucius und Lucius. 


\section{Authors:}

Sabine Bollig, Ph.D.

University of Trier

Department of Education

Section Social Pedagogy

Trier

54286

Germany

E-mail:bolligs@uni-trier.de

Zsuzsa Millei, Assoc. Professor

University of Tampere

Faculty of Education

Institute for Advanced Social Research

Kanslerinrinne 1

Tampere

FI-33014

Finland

E-mail: Zsuzsa.Millei@uta.fi 